\title{
Research Paper \\ The Effect of Parent Management Training (PMT) on the Reduction of Behavioral Symptoms in Children with Attention Deficit Hyperactivity Disorder
}

\author{
Nezamaddin Ghasemi" ${ }^{* 1}$, Latifeh Nori ${ }^{2}$, Sohrab Abdi Zarrin ${ }^{3}$
}

1. Assistant Professor, Department of Psychology, Faculty of Literature and Humanities, Salman Farsi University of Kazerun, Iran 2. M.A. in Clinical Psychology, Bandar Abbas Branch, Islamic Azad University, Bandar Abbas, Iran

3. Assistant Professor, Department of Educational Sciences, Faculty of Literature and Humanities, University of Qom, Iran

Citation: Ghasemi N, Nori L, Abdi Zarrin S. The effect of parent management training (PMT) on the reduction of behavioral symptoms in children with attention deficit hyperactivity disorder. Quarterly Journal of Child Mental Health. 2019; 6(2): 1-12.

http://dx.doi.org/10.29252/jcmh.6.2.2

\section{A R T I C L E I N F O}

\section{Keywords:}

Parent management training (PMT), attention deficit hyperactivity disorder (ADHD), behavioral symptoms

Received: 15 Apr 2018 Accepted: 13 Dec 2018 Available: 10 Aug 2019

\section{A B S T R A C T}

Background and Purpose: Attention Deficit Hyperactivity Disorder (ADHD) consists of a persistent pattern of inattention, hyperactivity, and impulsive behaviors which are more severe and common than what is typically observed in children with similar level of development. Some experts argue that all the therapeutic interventions should not focus only on the affected child, but instead they should take into consideration the parents and other family members too. Therefore, the present study was conducted to investigate the effect of Parent Management Training (PMT) program (focused on mothers) on the reduction of behavioral symptoms in children with ADHD.

Method: This study was a quasi-experimental research with pretest-posttest control group design. The study population included all the 7 to 12-year-old children with ADHD in Khanj city of Fars province in 2017. The sample consisted of 30 mothers of the mentioned children who were selected through purposeful sampling according to the inclusion and exclusion conditions of the study and then randomly assigned to either the experimental or the control group. PMT was offered to the experimental group in eight 90-minute sessions, i.e. two sessions per week; whereas the control group received no intervention. Conner's Parent Rating Scale (CPRS, 1987) and Depression, Anxiety \& Stress Scales (DASS-21, 1995) were administered to both experimental and control groups at pretest and posttest stages.

Results: Data analysis by analysis of covariance showed that PMT caused a significant difference in the scores of behavioral problems in the experimental group compared to the control group, either in the total score or in the subscales of conduct, social, and psychosomatic problems, anxiety, and shame $(\mathrm{P}<0.001)$, in such a way that the behavioral problems in the experimental group decreased significantly at the posttest stage and the effect size was $0.46(\mathrm{P}<0.001)$.

Conclusion: Based on the results of this study, it can be concluded that PMT can modify the emotional and behavioral problems in children with ADHD through correcting family interactive methods, teaching the parents how to behave, enhancing parents' understanding of the behavioral symptoms of the disorder, improving their attitudes towards the disorder, and using corrective punishment and reinforcement methods.

\footnotetext{
* Corresponding author: Nezamaddin Ghasemi, Assistant Professor, Department of Psychology, Faculty of Literature and Humanities, Salman Farsi University of Kazerun, Iran.

E-mail addresses: Nezamghasemi@yahoo.com
} 


\section{تأثير آموزش مديريت والدين بر كاهش علايم رفتارى كودكان مبتلا به اختلال نارسايى توجه فزون كنشى \\ نظام الدين قاسمى"'، لطيفه نورى'، سهراب عبدى زرين'}

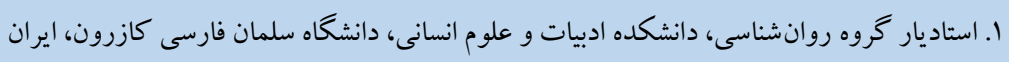

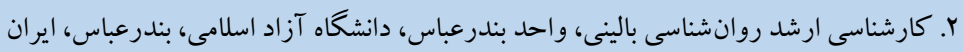

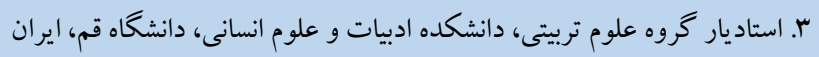

\section{جكيده}

زمينه و هدف: اختلال نارسايى توجه فزون كنشى، الكوى بايدار عدم توجه، فزون كنشى، ورفتارهاى تكانشى است كه شديدتر و شايعتر از

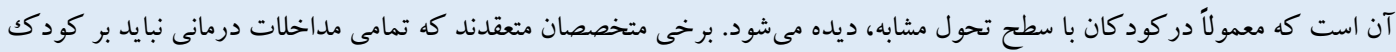

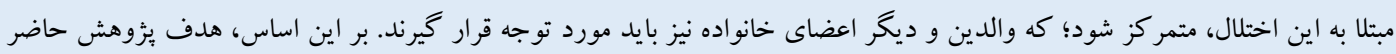

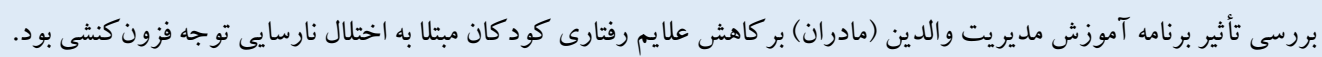

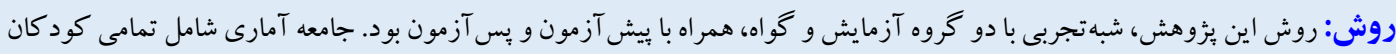

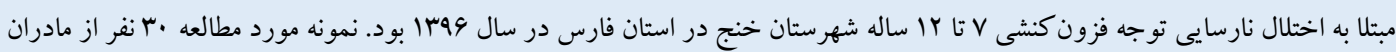

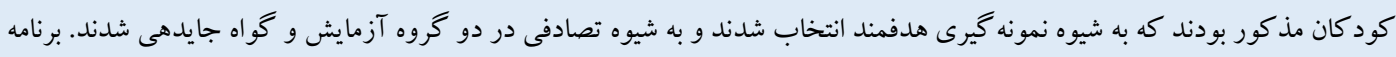

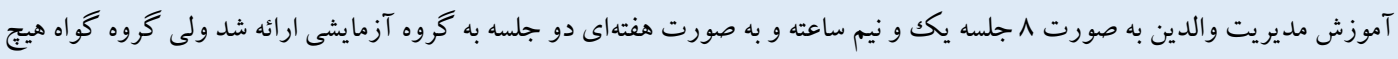

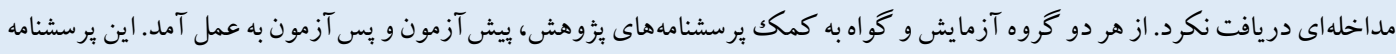

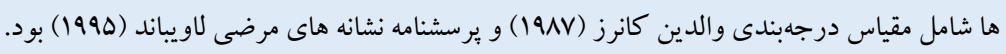

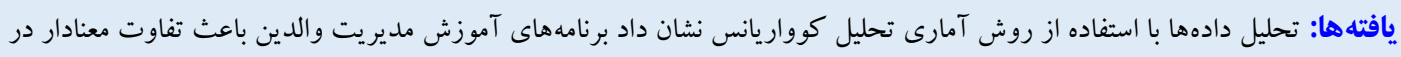

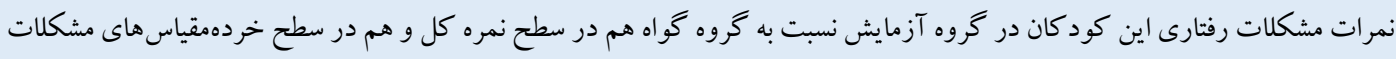

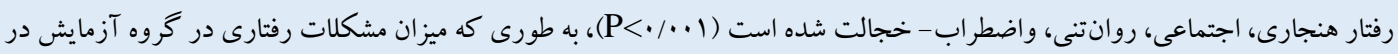

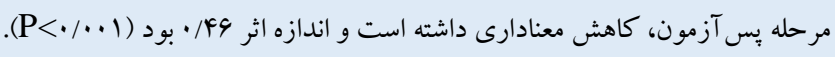

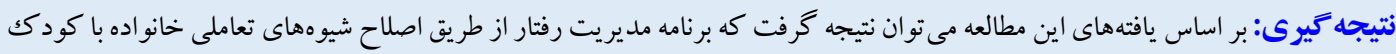

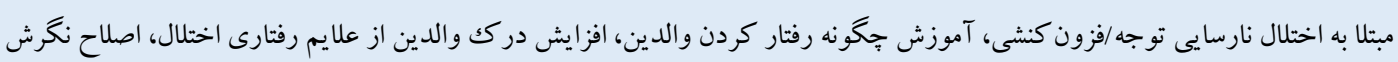

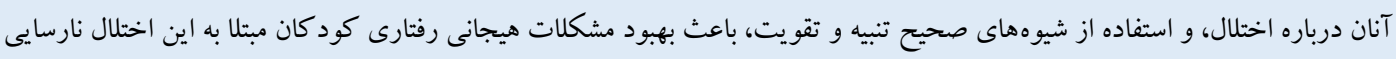

$$
\text { توجه / فزون كنشى مىشود. }
$$

مشخصات مقاله

كليدوازهها:

آموزش مديريت والدين،

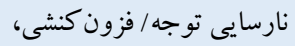

علايم رفتارى

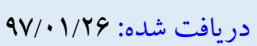

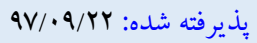

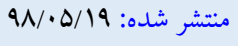

* نويسنده مسئول: نظام الدين قاسمى، استاديار گروه روانشناسى، دانشكده ادبيات و علوم انسانى، دانشكاه سلمان فارسى كازرون، ايران.

رايانامه: Nezamghasemi@yahoo.com

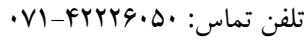


اختلـالهــاى روانى والـدين، همراه شـــند (11). در اين زمينه يثزوهشها حاكى از اين هسـتند كه بين رفتارهاى نامناسـبـ والد-كود كك و علايم

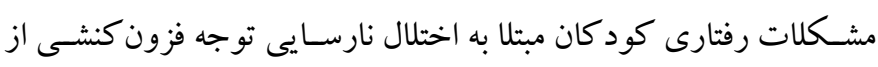

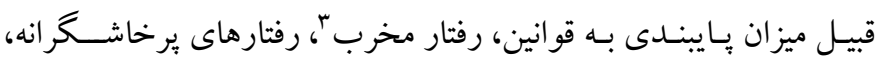

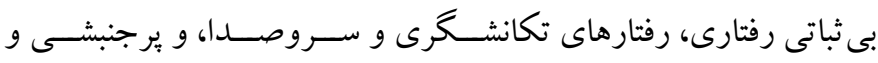

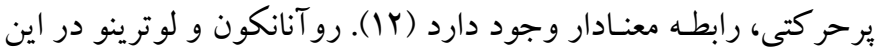

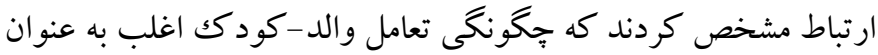

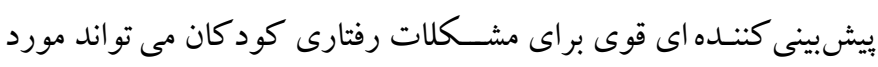

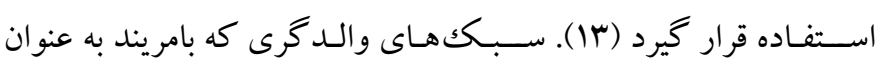
كار كرد مهار والدين معرفى مى كند (If) از نوع نظم و انضـباط نايايدار، نظارت ضعيف، سطوح بايين صميميت، و سطوح بالاى جديت مى توانند اثرات طولانى مدتى بر مشكلات رفتارى برون منمود و درونتمود (شكايت

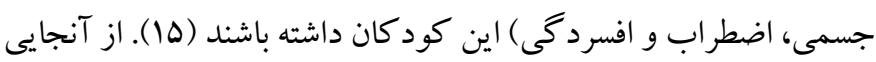
كه درمان قطعى براى اختلال نارسـايى توجه/فزون كنشى وجى وجود ند ندارد و

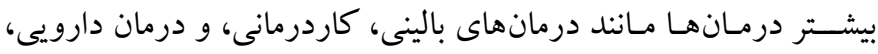
كو تاه مدت و بر حذف نشـانهها تاكيد دارند؛ به نظر مى رسـد درمانهاى طولانى مدت، جندبعدى، و خانو ادهمحور مى تواند مؤثرتر باشند . يكى از

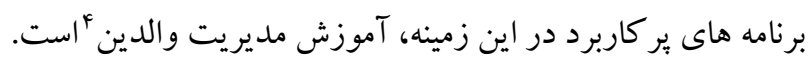
در اين نوع درمان، برنامه اصلاح رفتار كودكك در محيط طبيعى منزل

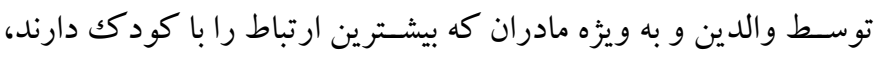

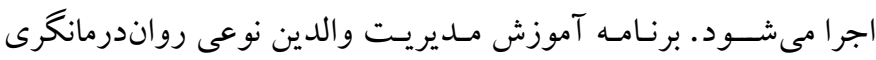
كود كـان اســت كـه بـا تغيير رفتـار شــناختى - عاطفى والدين در رفتار

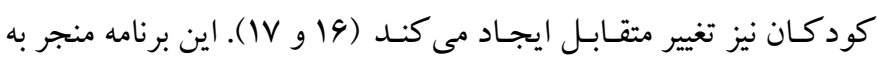

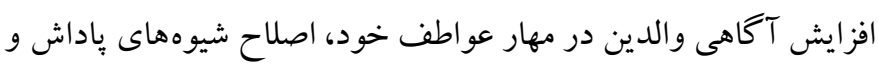

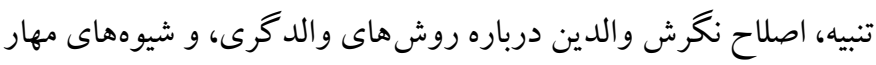

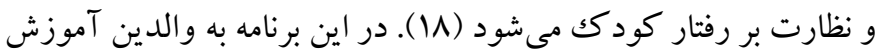

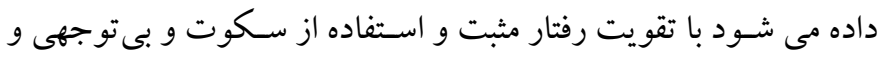

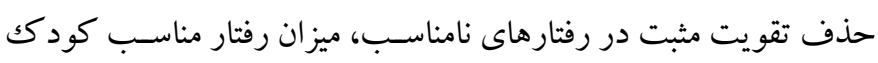

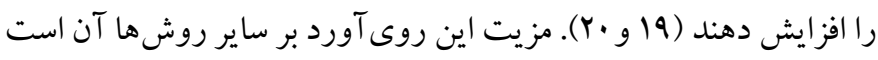
كـه جنبـه هـاى مختلفى از عملكرد والـدين و خـانواده را تحت تأثير قرار
مقلدمه

كود كان قشر عمدهاى از جمعيت جهان را تشكيل مىدهند به طورى كه

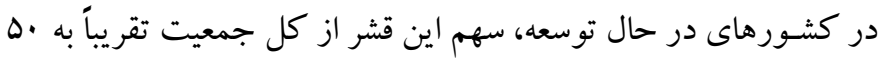

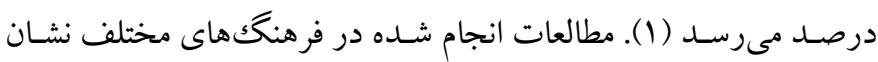
داده اسـت درصد قابل توجهى از كودكان سنين مدرسه و قبل از مدرسه

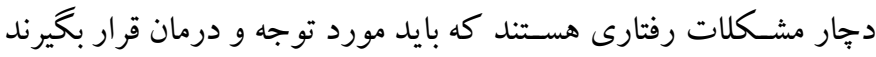

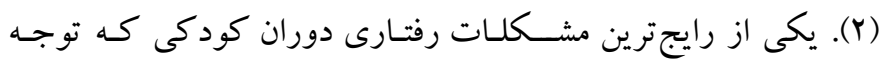

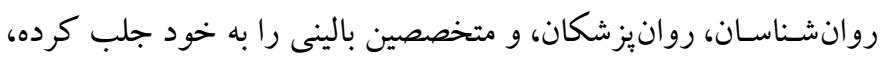

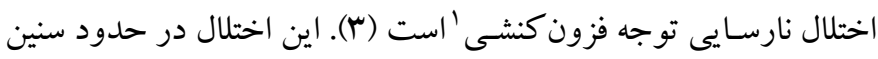

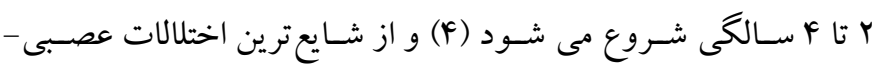
رفتارى دوران كودكى اسـت، به طورى كه س تا V درصـد كود كان بدان

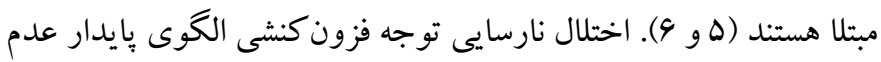

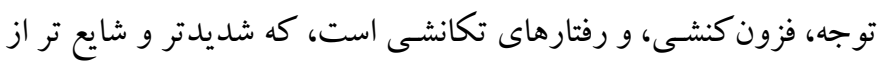

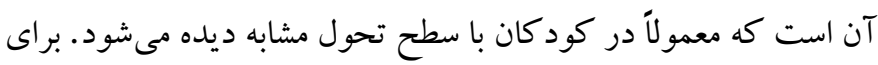

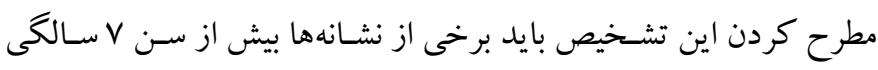

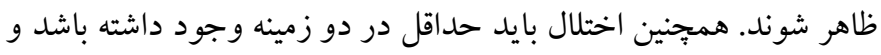

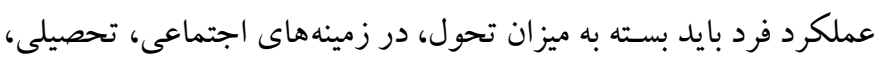

يا شغلى مختل شده باشد (V).

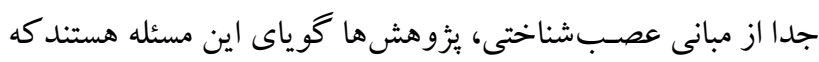

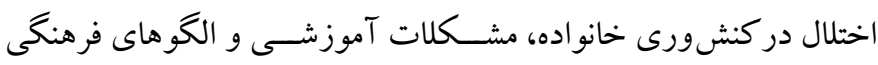

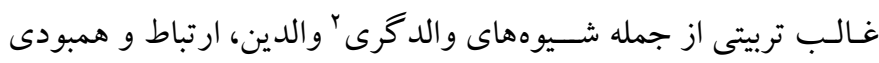

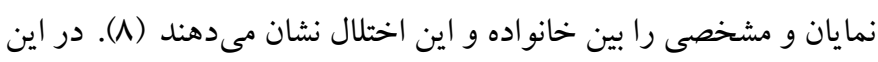

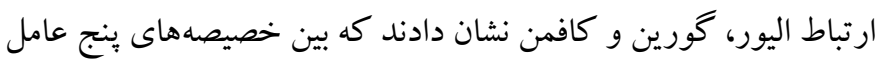

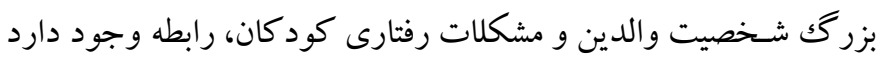

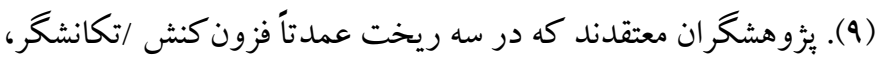

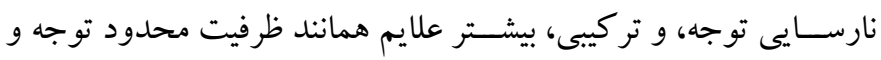

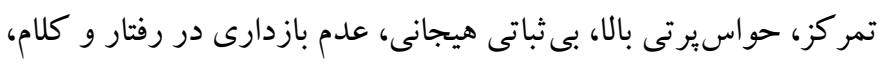

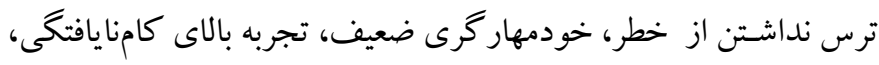

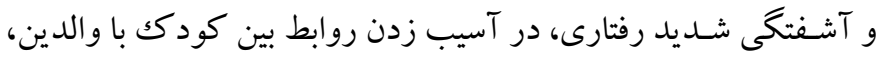

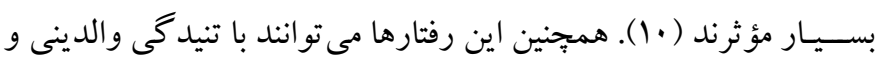

1. Attention Deficit Hyperactivity Disorder (AD/HD)

2. Parenting styles 
بر اين اسـاس، هدف اين يزوهش بررسى تأثير آموزش مديريت والدين

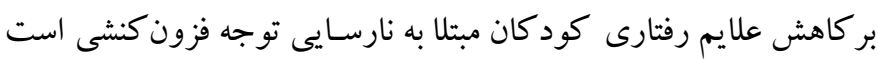

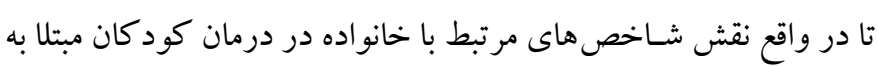
اختلال را آشكار سازد.

روش الف) طرح هثوهش و شر كت كنند

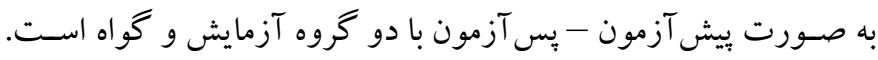

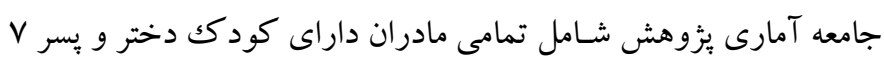

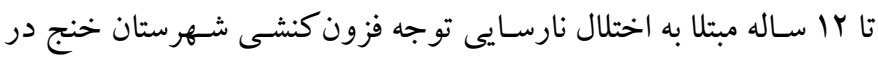

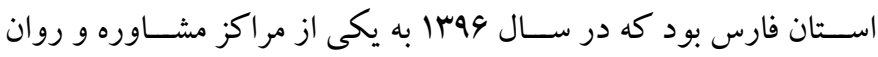

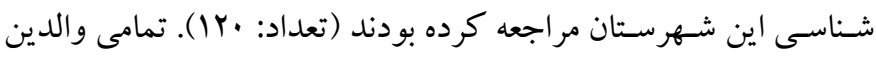
مر اجعه كننده به مراكز مشـاوره و روان شناسى مورد بررسى ابتدايى قرار

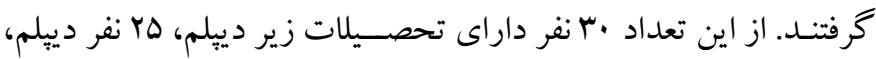

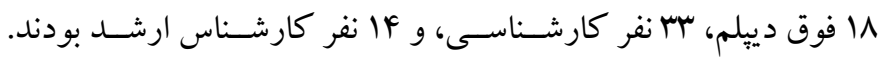

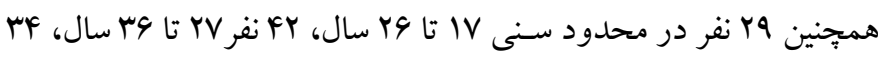

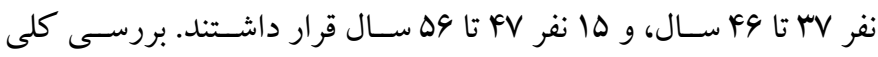

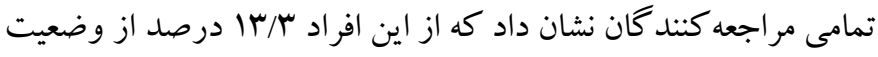

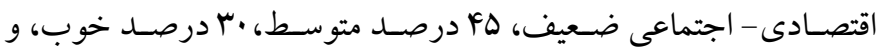

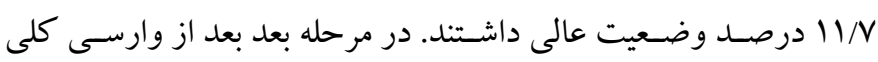
مر اجعه كنند گان، تعداد ·ـ نفر از مادران كه مايل به شـركت در در جلسات

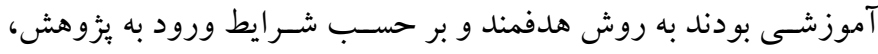

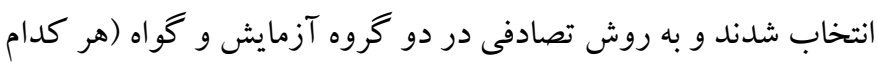

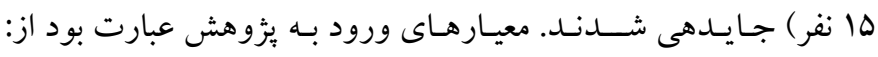
تشـخيص اختلال نارسـايى توجه فزون كشى از هر سـه ريخت بر اسـاس ملاككهاى تشخيصى، مصرف دارو توسط كودكى، عدم ابتلا به اختلالات روانى در مادر و كودكك، و دامنه سنى كود كك بين V تا Y I سال. همجِنين

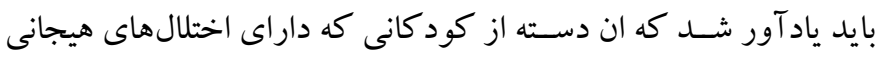
رفتارى همبود بودند از فهرست نمونه خارج شدند. ب) ابزار: براى جمع آورى اطلاعات از ابزارهاى زير استفاده شد:
مىدهـــ و بر نحوه نظـارت و مـديريت والدين بر رفتارهاى كودكك و از همه مهم تر بر هماهنگ

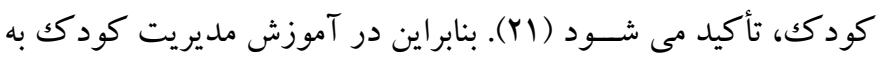

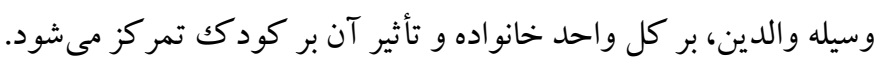

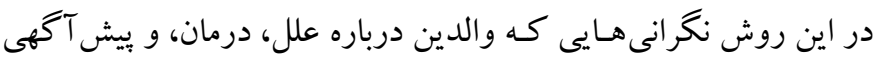

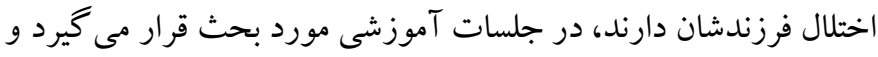

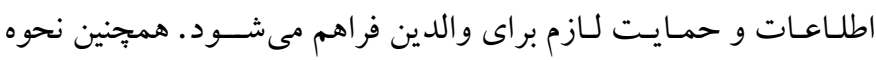

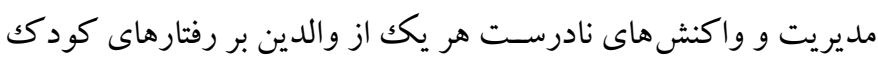

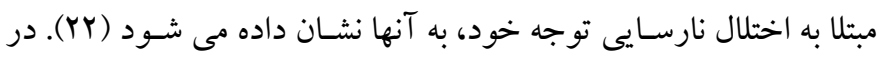

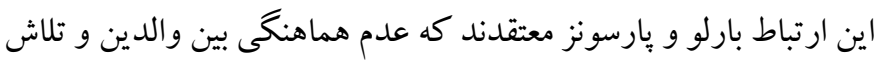

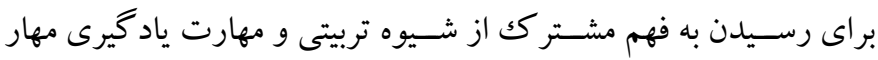

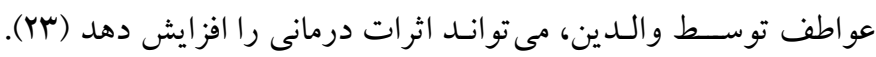

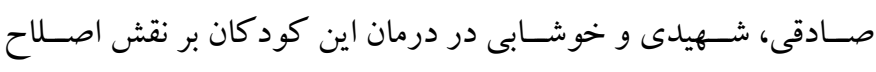

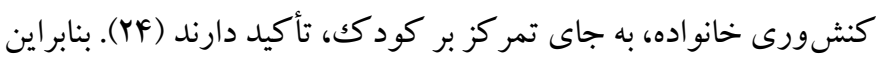

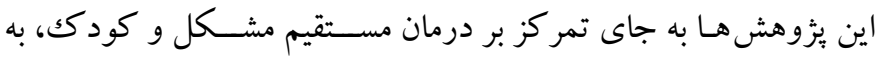

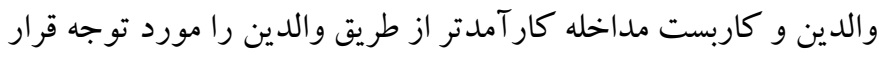

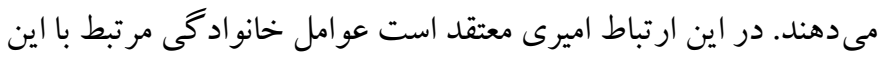

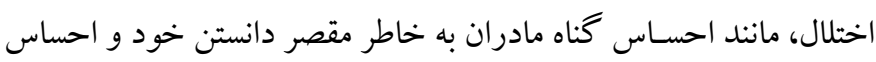

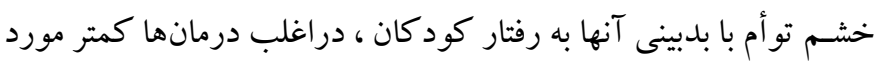
توجه قرار گرفته است (rQ)

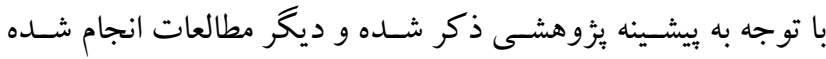

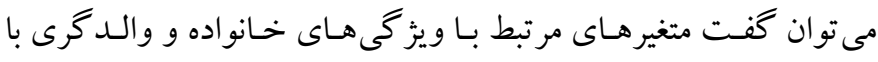

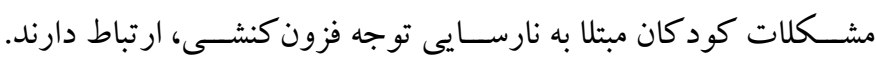

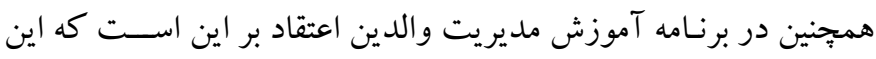

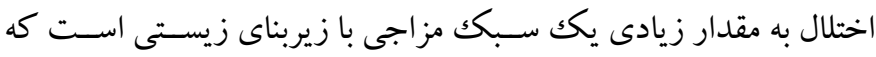

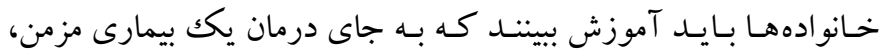

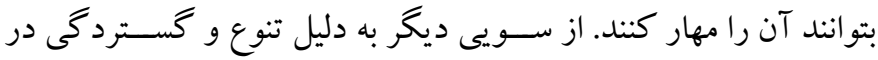

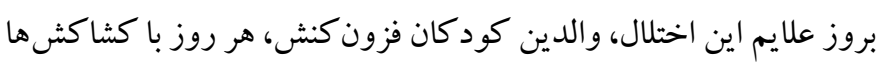

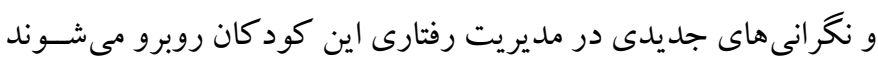

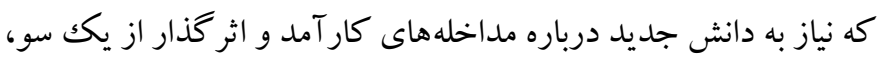

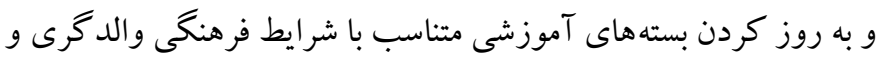
شناخت ضعف هاى بومى اين برنامهاى مداخلهاى، بسيار ضرورى است. 


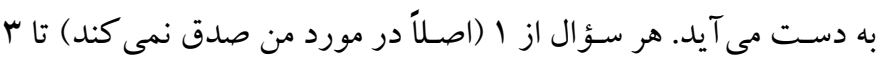

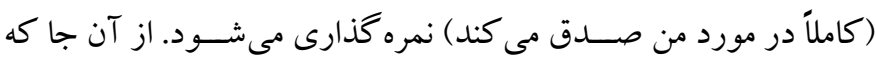

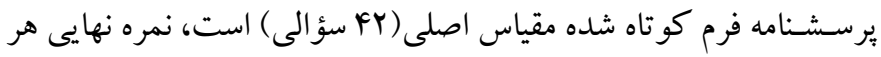

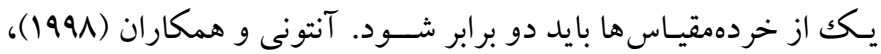

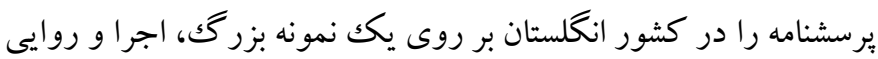

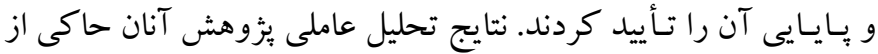

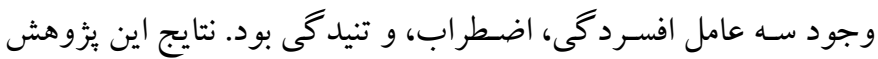

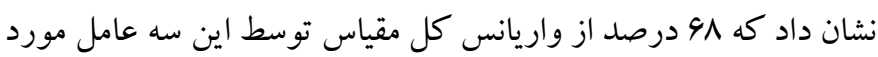

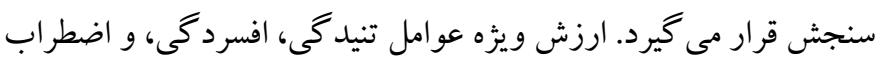

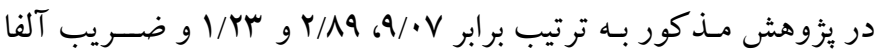

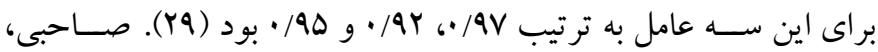

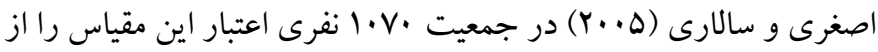

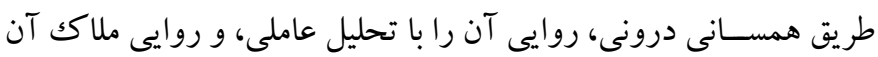

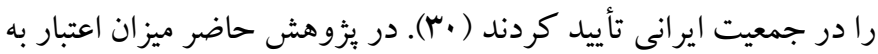

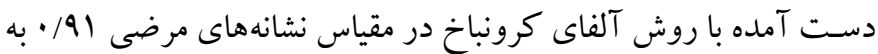

دمت آمد.

ج) برنـامه مداخلهاى: در اين مطالعه طرح جلســات آموزش مديريت

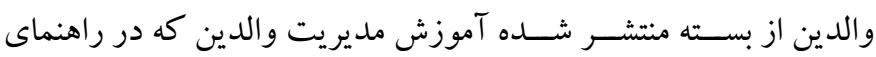
درمانى بار كلى ارايه شــده (1) و در مطالعات مختلفى مورد اسـتفاده قرار

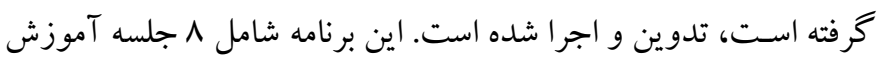
1/ه ساعته است كه به صورت هفتهاى دو بار و به صورت انفرادى توسط

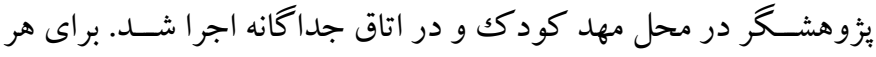

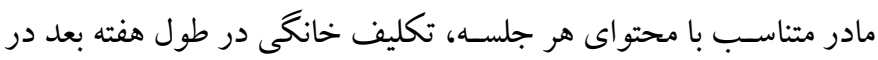

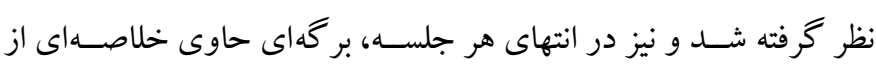

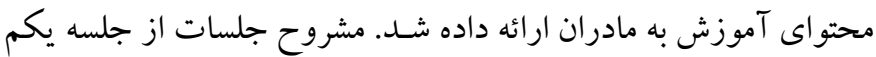
تا هشتم به تلخيص در جدول زير آورده شده است.
3. Depression, Anxiety and Stress Scale(DASS-21)

4. Lovi Bond

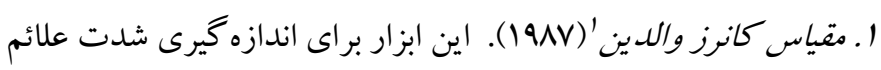

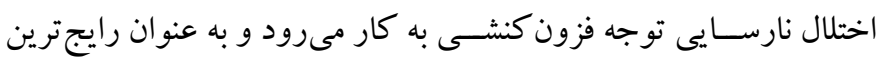

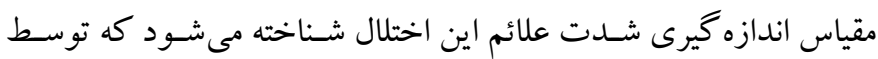

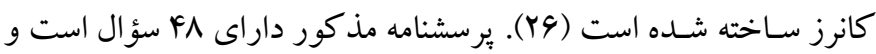

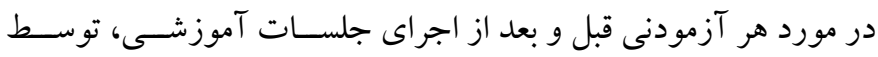

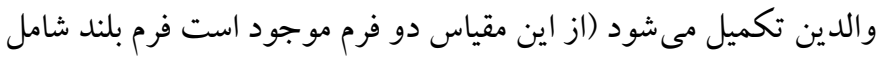

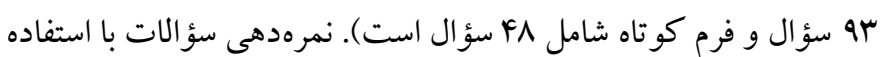

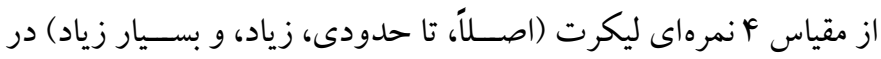

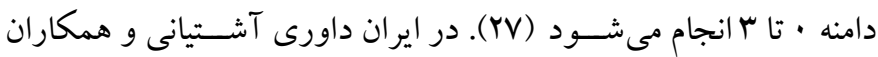

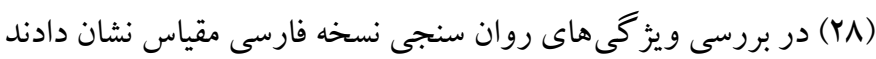

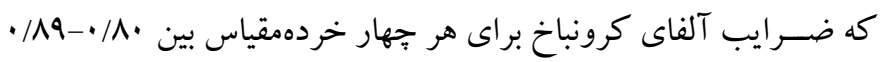

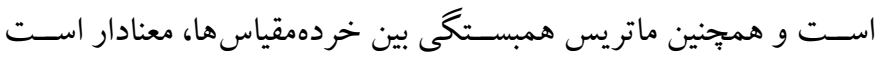

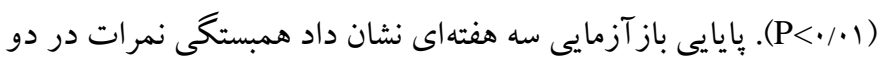

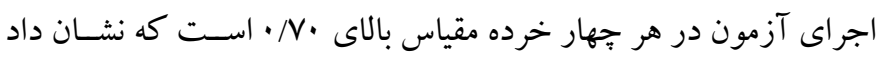

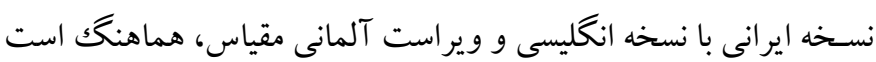
(YN)

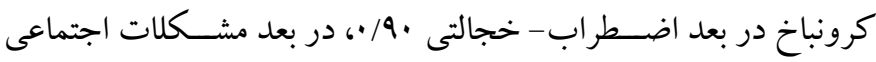

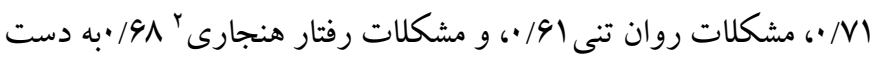

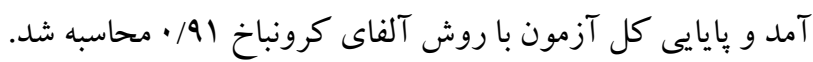

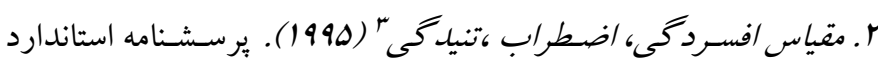

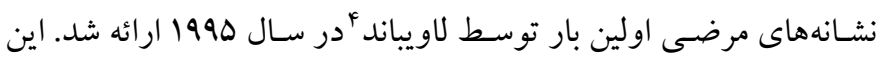

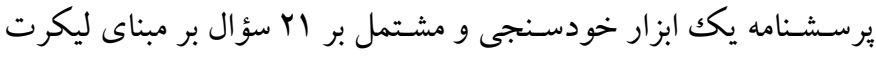

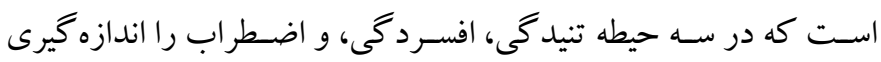
مى كند. سطوح افسردگى، تنيدگى، و اضطر اب در اين مقياس در هـ سطح عادى، خفيف، متوسط، شـديد، و بسيار شديد طبقهبندى شده است. هر

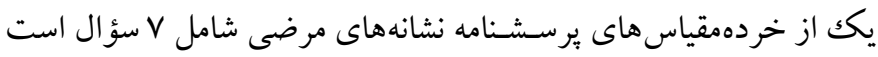

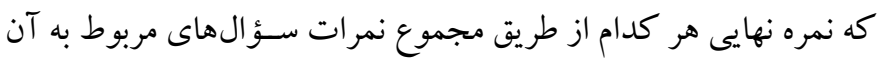

1. Canners Parent Rate Scale (CPRS)

2. Conduct 


\section{جدول ا: برنامه آموزش مديريت والدين كود كان با اختلال نارسايى توجه فزون كنشى، بار كلى (A)}

\begin{tabular}{|c|c|c|c|}
\hline تكليف & 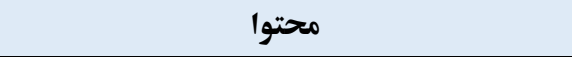 & هدف & 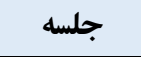 \\
\hline ت تكنيك تحسين و توجه & توضيح اختلال، سببشناسى، علايم، درمانهاى رايج، & تغيير نخرش والدين به اختلال و به رفتار مشكل ساز & جلسه يكم \\
\hline تكميل جدول تقويت مثبت & توضيح تقويت مثبت و تفكيكى، شناسايى انواع & كاربرد بِاداش و امتيازها & 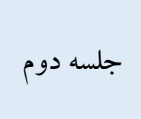 \\
\hline تكنيك تحسين القايى، تكنيك وقفه & 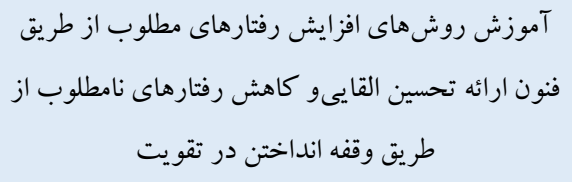 & هدف يادگيرى فنون تحسين و تشويق & 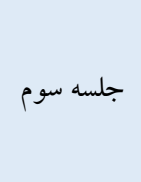 \\
\hline تكليف توجه كردن و ناديده كرفتن & آموزش تكنيك توجه مثبت به فرمانبردارى از دستور & 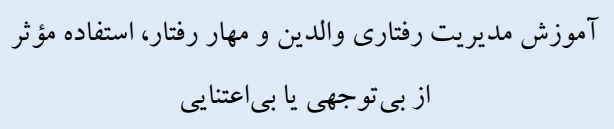 & جلسه جهارم \\
\hline تكنيك جريمه و محروم سازى & توضيح شكلدهى رفتار خاص توسط والدين، استفاده & بهبود رفتار كود كك در مدرسه و منزل و كاهش رفتارهاى & جلسه ينج \\
\hline استفاده از تكنيك حذف بِاداشهاو & تدوين برنامه اقتصاد يتهاى در خانه & جلو گيرى از بدرفتارى هاى شديد & 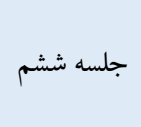 \\
\hline خانه و مدرسه) و جمع بندى آموخته ازتها هام تكليف (ارتباط & كاربرد تنبيه بدنى & اصلاح نخرش والدينى كه تنبيه را به عنوان روش اوليه & جلسه هفتم \\
\hline انجام تكليف (ار تباط خانه و مدرسه) & جمعبندى آمو ختهها، آهوزش تسليم در برابر مشكلات & 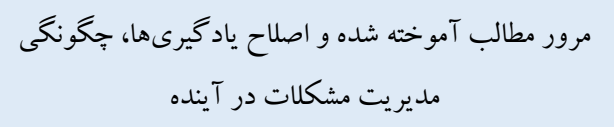 & جلسه هشتم \\
\hline
\end{tabular}

ييش آزمون و قرار دادن آزمودنى ها در دو گروه آزمايش و گو اه به شكل قرعه كشى، برنامه آموزش مديريت والدين براى كروه آزمايش اجرا شدر.

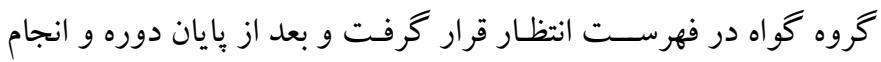
يس آزمون به دليل رعايت مسـايل اخلاقى، دوره آموزشسى براى آنان نيز

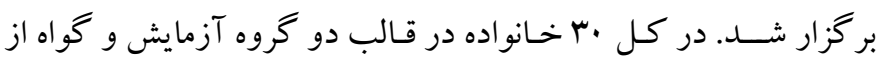

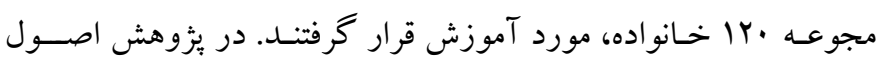

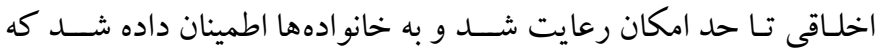
اطلـاعـات بـه دسـت آمده كاملا به صـورت محرمانه باقى خو اهد ماند. همجينين به آنان كفته شـد كه هر زمان كه تمايل داشته باشند مى تواند از شـركت در جلسـات خوددارى كنند. للازم به ذكر اسـت كه دادههاى به دست آمده از ابزارهاى يزوهش در دو سطح آمار توصيفى و استنباطى به روش تحليـل كواريـانس بـه كمكك نرمافزار SPSS-22 تجزيه و تحليل
د) روش اجرا: بعد از كسـب مجوزهاى للازم علمى و اجر ايى و انتخاب افراد نمونه، از والدين (مادران) قبل از اجراى مداخلات آزمايشى، اجراى مقياس كانرز والدين به عنوان بيش آزمون (براى ثبت خط بايه) و بس از

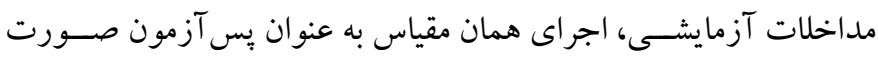

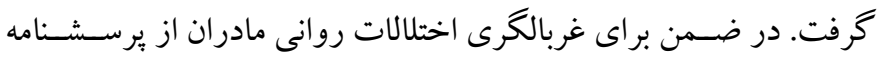
نشـانهاى مرضى استفاده شد. همزمان با ارائه ير سشنامه ها جه در مرحله بيش آزمون و جهه در مرحله پِ آزمون، يُزوهشكر با حضور در جلسات، توضيحاتى را در مورد نحوه كامل كردن يرسشنامه به مادران ارائه كردند. روش اجرا بـه اين شــكل بود كه ابتدا به صــورت فر اخوان در ســطح شـهـرسـتان، تمامى خانو ادههايى كه داراى فرزندى با تشـخيص اختلال نارسـيى توجه / فزون كنشى بودند جهت شر كت در دوره دعوت شدند. تمامى خانو ادههايى كه داراى فرزند مبتلا به اين اختلال بر اساس تشخيص

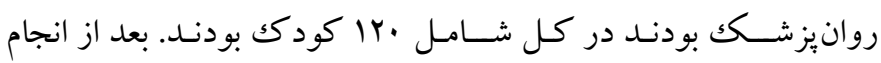


رفتـار هنجارى اجتماعى، روانتنى، و اضـطراب- خجالتى در جدول r

يافتهها

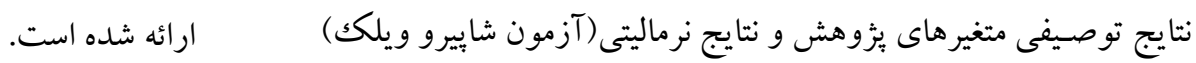

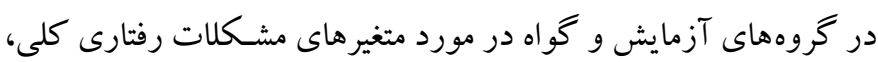

\begin{tabular}{|c|c|c|c|c|c|c|c|c|c|c|c|}
\hline \multirow[b]{2}{*}{$\mathbf{P}$} & \multicolumn{3}{|c|}{ كواه } & \multicolumn{6}{|c|}{ آزمايش } & \multirow[b]{2}{*}{ كروه } & \multirow[b]{2}{*}{ متغير } \\
\hline & $\mathbf{Z}$ & SD & $\mathbf{M}$ & $\mathbf{n}$ & $\mathbf{P}$ & $\mathbf{Z}$ & SD & $\mathbf{M}$ & $\mathbf{n}$ & & \\
\hline \multirow{3}{*}{$\cdot \pi$} & & $\Lambda / \Lambda$. & $r \cdot F / \lambda$. & 10 & & & $9 / 14$ & $19 \mathrm{~V} / .9$ & 10 & بيش آزمون & مشكلات رفتارى \\
\hline & ./А९৭ & 91.0 & $191 / 99$ & 10 & / &.$/ 909$ & $V / 19$ & $|r| / 9$. & 10 & يس آزمون & كل \\
\hline & & $1 / M$ & $90 / 1 \pi$ & 10 & & & $r / V q$ & $9 \pi / 99$ & 10 & ييش آزمون & مشكلات رفتار \\
\hline \multirow[t]{2}{*}{$\cdot / 19$} & $\cdot / M V$ & r/q & $91 / N \pi$ & 10 &.$/ 1 F$ & ./AVG & $r / v q$ & $r \Delta / \wedge q$ & 10 & مِس آزمون & هنجارى \\
\hline & & $r / 4 I$ & $r q / v q$ & 10 & & & I/AV & $r V / 99$ & 10 & يِيش آزمون & \\
\hline \multirow[t]{2}{*}{$\cdot / r q$} & ./^९৭ & $r / \cdot \cdot$ & $r q / \Lambda$. & 10 & וT/ &.$/ 911$ & $r / T r$ & $r V / 90$ & 10 & يَس آزمون & \\
\hline & $\cdot$ / AVG & $\begin{array}{l}r / \cdot \cdot \\
1 / \Delta V\end{array}$ & $r r / r q$ & 10 & $\cdot / r \Lambda$ & ./А९V & $\begin{array}{l}r / M r \\
r / W V\end{array}$ & $\begin{array}{l}r r / r . \\
r y / .\end{array}$ & 10 & بِيش آزمون & مشكلات روان تنى \\
\hline$\cdot / r V$ & & $r / \Delta r$ & $r \Delta / f$. & 10 & & & $r / 19$ & TF/AG & 10 & بيش آزمون & مشكلات اضطرابى - \\
\hline$\cdot /$ / &.$/ 94 A$ & $1 / 91$ & $r \Delta / 1 T$ & 10 & $\cdot / \mu F$ & . /QYr & $1 / 14$ & $19 / 1 \pi$ & 10 & يُس آزمون & خجالتى \\
\hline
\end{tabular}

واريانسها (آزمون لوين) و همخنى شـيب رگرســيونى نشــان داد كه ييش فرض برابرى واريـانس دو گروه در مورد متغيروابسـتـه مورد تأييد

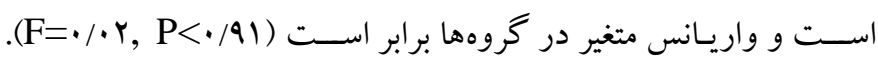
همجِنين آزمون بررسى اثر تعاملى ييش آزمون و گروه در مورد متغيرهاى

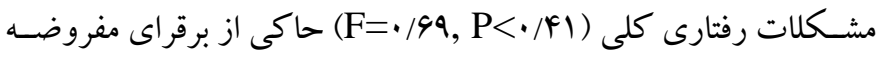
همخنى ضـرايب رَرسيون است. بدين ترتيب، انجام آزمون بارامتريكك آنكوا بلامانع است. در جـدول ب نتـايج تحليـل كوواريـانس مربوط بـه تـأثير آموزش مديريت والدين در كاهش شدت مشكلات رفتارى كلى كود كان مبتلا به اختلال نارسايى توجه فزون كنشى نشان داده شده است.
نتايج جدول Y نشـان دهنده تفاوت ميانگين متغيرهاى بثزوهش در دو

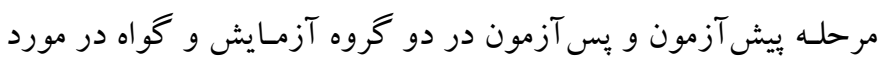

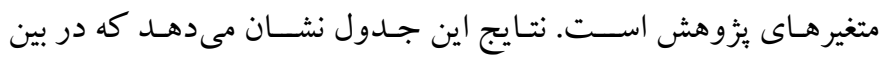

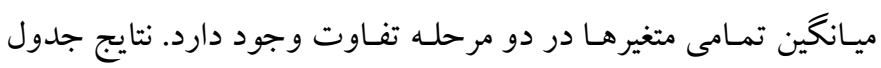

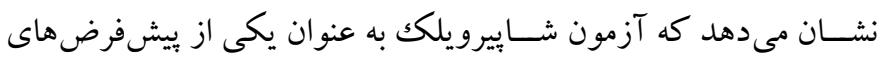
نرماليتى تأييد مىشود يعنى توزيع نمرات متغيرهاى يزوهش نرمال است.

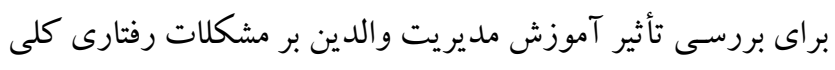

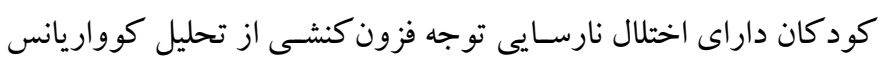

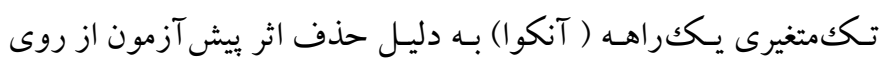

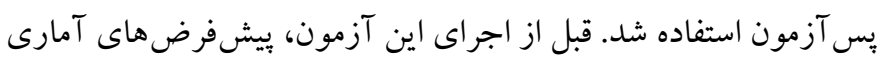

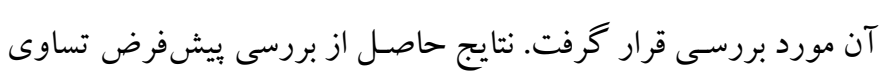

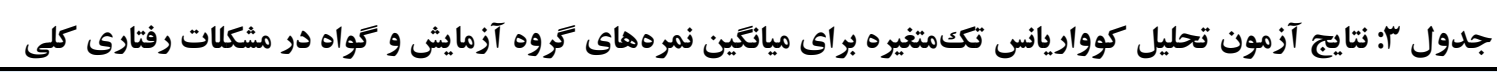

\begin{tabular}{|c|c|c|c|c|c|c|}
\hline ضريب اتا & $\mathbf{P}$ & F Tاره F & ميانگين مجذورات & df & مجموع مجذورات & منبع \\
\hline$\cdot / \cdot r$ & $\cdot / M V$ & $\cdot|\Lambda|$ & rG/ro & 1 & rG/TD & ييش آزمون \\
\hline \multirow[t]{2}{*}{$\cdot / 44$} &.$/ \cdots 1$ & $V \cdots / 4 q$ & rIr. & 1 & $M I Y \cdot I / r Y$ & كروه \\
\hline & & & FG/.FYG & Yq & $119 \mathrm{~V} / \mathrm{VD}$ & خطا \\
\hline
\end{tabular}




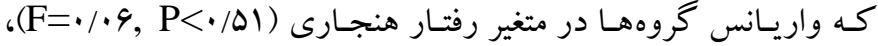

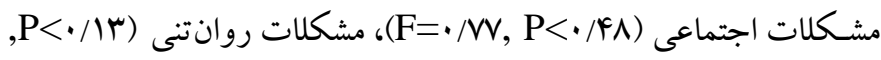

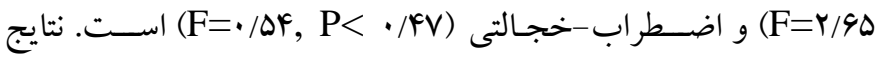
آزمون بـاكس براى بررســى برابرى مـاتريس كوواريانس هاى متغيرهاى وابسته نشان داد كه ماتريس كوواريانس آزمون باكس در دو گروه برابر بر برسي

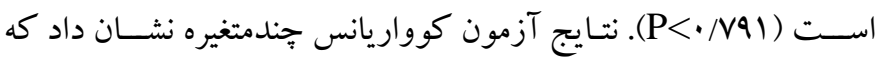
تمـامى زيرمقيـاس هاى مشـكلات رفتارى از مركز ثقل برابرى برخوردار هستند و به عبارت ديخر بين دو گروه در زيرمقياسها تفاوت معنىدارى وجود دارد (P/ه) براى بررسى تفاوت گروه آزمايش و گو اه در زيرمقياس هاى مشـكلات

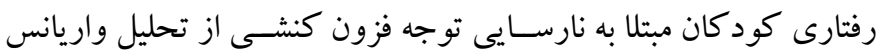
تككمتغيره اسـتفاده شـد كه نتايج حاصـل از آن در جدول \& ارائه شـده

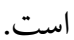

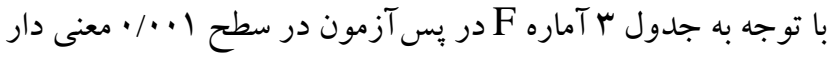

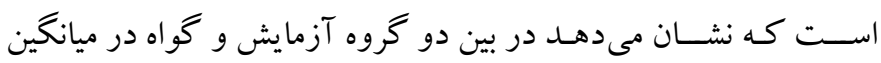
نمرات مشكلات رفتارى كود كان، تفاوت معنى دار وجود دارد. اندازه اثر

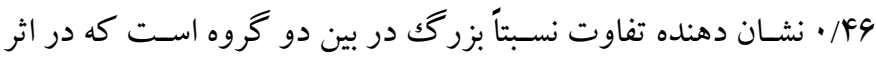

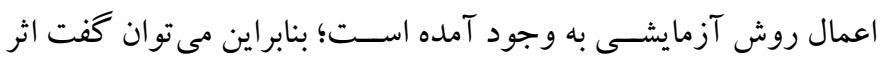
متغير مستقل گروه (آموزش مديريت والدين) بر متغير وابسته مشـكلات

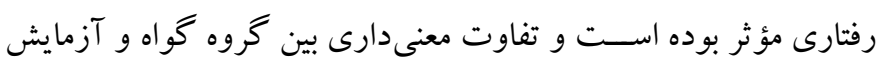

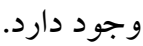

براى بررسـى تـأثير آموزش مـديريـت والـــين بر زيرمقيـاسهـاى مشكلات رفتارى كود كان مبتلا به نارسايى توجه فزون كنشى (مشكلات

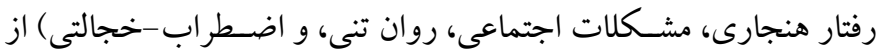
تحليل كوواريانس جندمتغيره( مانكو ) اسـتفاده شــــ نتايج آزمون لوين براى بررسى همخى واريانس هاى متغيرهاى وابسته در دو گروه نشان داد

جدول ع: نتايج آزمون تحليل كوواريانس تككتغيرى كروه آزمايش و كواه در مؤلفه هاى مشكلات رفتارى

\begin{tabular}{|c|c|c|c|c|c|c|}
\hline توان آمارى & ضريب اتا & $\mathrm{p}$ & $\mathrm{F}$ & ميانكين & كروه & مؤلفه \\
\hline 1 & • &.$/ \cdots 1$ & $F / I F$ & $\begin{array}{l}F r / F q \\
N F F / \Delta q\end{array}$ & $\begin{array}{l}\text { كزمايش } \\
\text { كواه }\end{array}$ & مشكلات رفتار هنجارى \\
\hline 1 & $\cdot /$ TF & $\cdot / \cdots 1$ & $1 / \wedge \mathrm{V}$ & $\begin{array}{l}\text { I/AV } \\
\text { QN/Y. }\end{array}$ & كواه & مشكلات اجتماعى \\
\hline 1 &.$/ 49$ & $\cdot / \cdot 1$ & 1 & $\begin{array}{l}\Lambda / F \\
F / q / Y q\end{array}$ & كواه & مشكلات روان تنى \\
\hline 1 & .194 & $\cdot / \cdots 1$ & T/RG & $\begin{array}{c}F / V q \\
\Delta \wedge V / \cdot r\end{array}$ & كَزمايش & مشكلات اضطر ابى - خجالتى \\
\hline
\end{tabular}

\section{بحث و نتيجه تميرى}

هدف بزوهش حاضسر بررسسى اثربخشسى آموزش مديريت والدين در

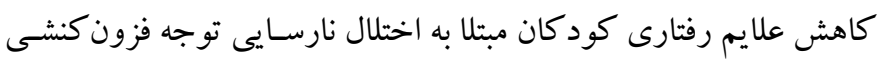
بود. نتايج نشـان داد كه روش آموزش والدين بر كاهش شدت مشكلات رفتارى كود كان مبتلا به اين اختلال در مؤلفه هاى مشكلات رفتار هنجارى، مشكلات اجتماعى، مشكلات روانتى، و مشكلات مرتبط با اضطراب و خجـالـت تأثير معنـادار داشــته اســت. اين يافته با بخشــى از يافتههاى
نتايج جدول F نشــان مى دهد كه آماره F براى هر جهار زيرمقياس

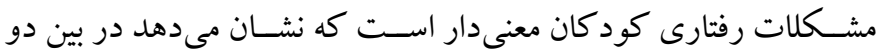

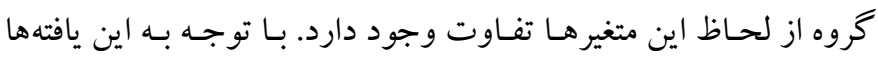
مىتوان كفـت برنامه آموزش مديريت رفتار مادران باعث تغيير در ميزان

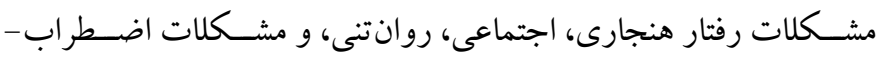


يكك مشكل، نه بيمارى برخورد كنند و با كاستن از اضطراب و تنيدگى

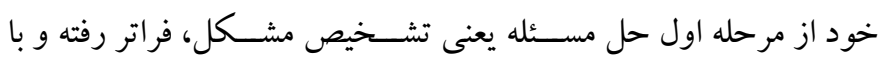

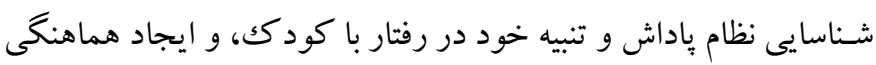
والدين در اسـتفاده از مديريت رفتارى، الكوى تعاملى منفى خانواده را كاهش داده و از شدت مشكلات رفتارى كود كان بكاهند. سـاير يافته هاى اين مطالعه نشـان داد اين روش آموزشسى در كاهش مؤلفه هاى مشـكلات رفتارى از قبيل مشــكلات رفتار هنجارى كود كان

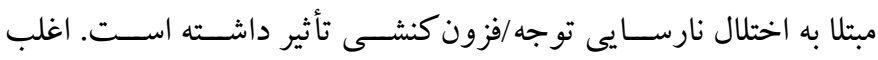

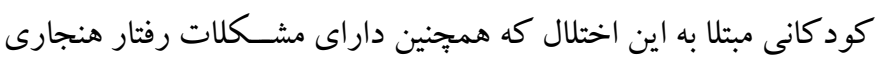

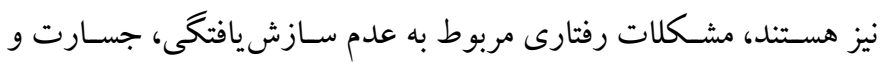
رفتـار قـانونشــكنـانـه، كوش نـدادن به حرف والدين و عدم اطاعت از دستورات آنها، و نقض قوانين جامعه در آينده (مانند دروغ گفتن، دزدى، فرار از مدرسـه، خود كشى، و سوء مصرف مواد) را بروز مىدهند (1)).

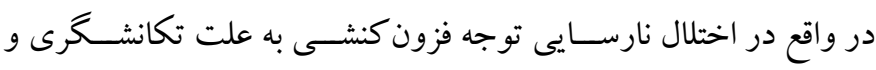

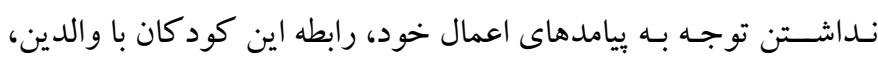
همر اه با تنش مىشـود و تضاد ميان كودك و مادر در سنين ييشدبستانى تا دوران نوجوانى ادامه مى يابد و اين موضــوع باعث مى شــود كه اين

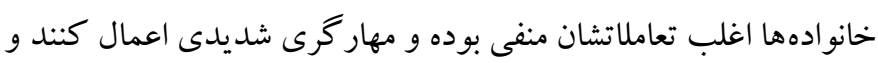

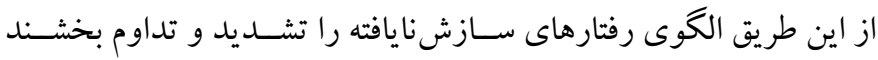

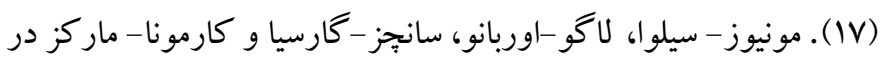

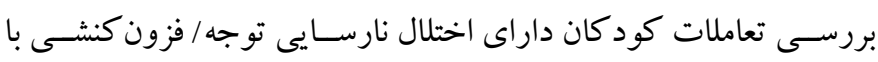

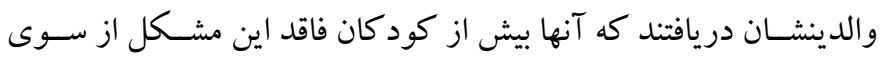
والدين، دستور دريافت مى كنند، سـرزنش و توبيخ مىشـوند، و از شيوه

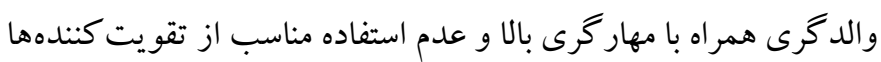
برخوردار هســتند (11)؛ بنابراين بر اســاس بيشـينه ذكر شـــه در تبيين اثربخشى اين روى آورد در كاهش مشكلات رفتارى اين كود كان مىتوان

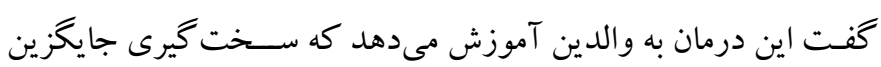
قاطعيت، تنبيه جايخزين گفتخوى متقابل، و مهارگرى جايخزين مديريت رفتارى والدين شـود. در اين زمينه بار كلى معتقد اسـت آموزش والدين موجب افزايش شـناخت آنان از ماهيت اختلال شده و اعتماد به خود آنها
يُزوهش هاى بِفيفنر و هاكك (·r)، اليور و همكاران (9)، و ساير بثزوهشها

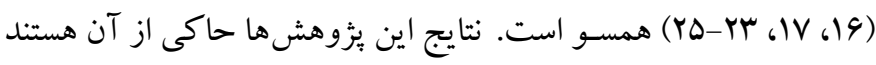
كه آموزش والدين در استفاده صحيح از تكنيك هاى رفتارى براى مهار رفتارهاى فرزندانشـان، نتايج مثبت در كاهش سـازش نايافتكى كود كان مبتلا به اختلال نارسـايى توجه فزون كنشسى دارد. بنابر اين بر اسـاس نتايج

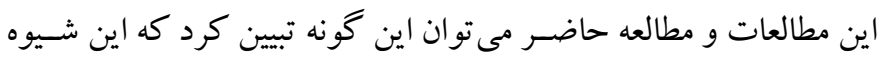
مداخلاتى باعث افزايش آكاهى والدين در مهار عواطفشــــان، اصسـلاح

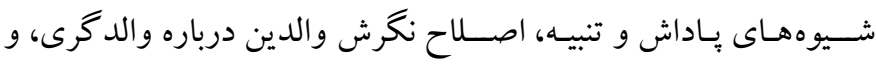

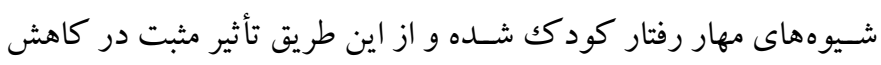
مشكلات رفتارى كود كان ايجاد كرده است. همجنين بر اساس روى آورد

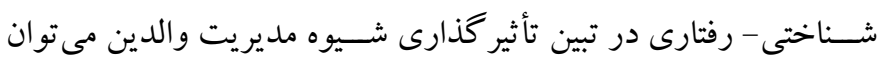

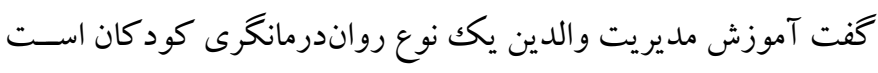

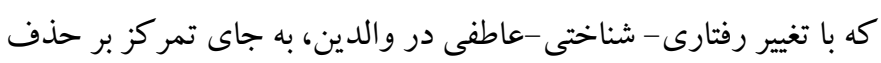

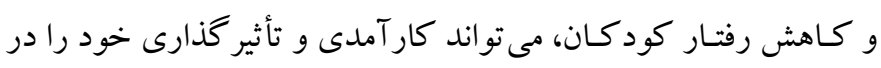
درمان اين اختلال اعمال كند. كود كان مبتلابه اختلال نارسـايى تو جه فزون كنشى علاوه بر سه نشانه

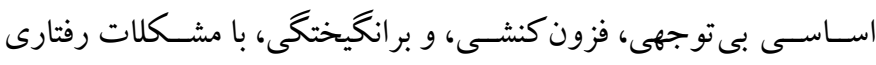

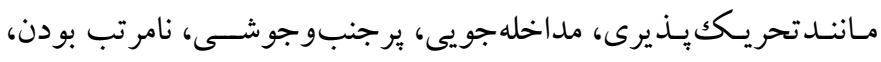

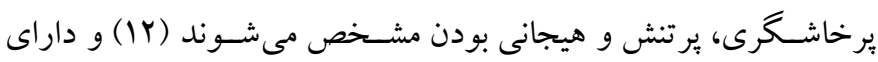

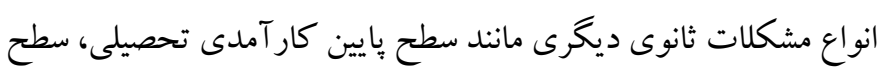

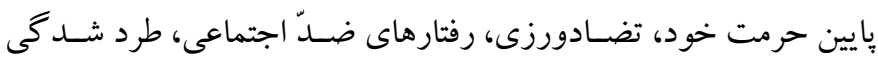

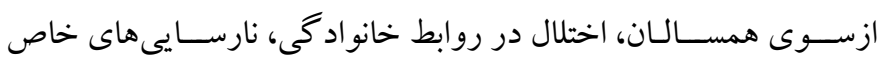
شـناختى وفر اشـناختى، نارسـايى هاى خاص حسى -حر كتى، و مشكلات

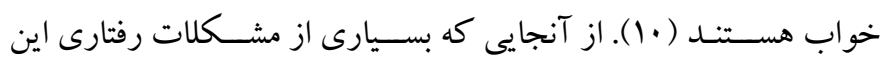
كود كان در بستر خانواده و به خصوص در ارتباط با مادر به وجود آمده و تداوم ييدا مى كنند، آموزش به مادران بهعنوان بيشترين و تأثير گذارترين عـامـل بر كودكـان از طريق آموزش توجه مثبت، ناديده انگارى، كاربرد

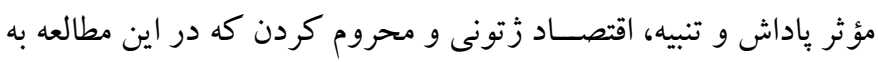
آن توجه زيادى شـده اسـت، مى تواند باعث اثربخشى اين شسيوه درمانى

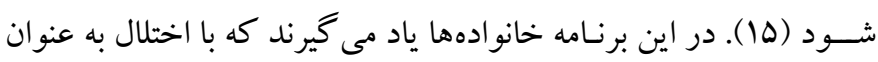


همزمـان كـه كودكك و خـانو اده از رســانـها و محيط اجتماعى دريافت

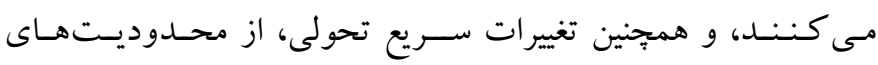
روششناسى اين بزوهش است كه بايد در استنباط از نتيجه كيرىها به آن توجه لازم داشـت و در مطالعات آينده براى رفع اين محدوديتها اقدام

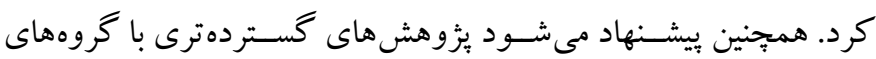

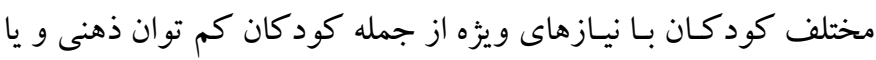
اوتيسـم با هدف بومىسـازى تكنيككهاى درمانى انجام بذيرد. در سطح

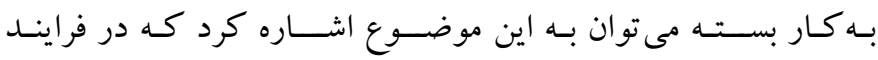
برنامهريزى هاى درمانى اختلال نارسايى توجه/فزون كنشى در سطوح خرد و كلـان جـامعه، بايد علاوه بر اقدامات درمانى متمر كز بر كود كك، ديخر

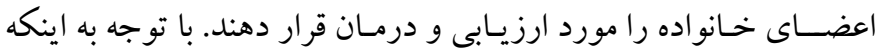
اغلـب خـانو ادههـاى ايرانى از ســـككهاى تعاملى خاص خود برخوردار

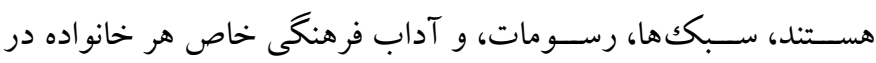
بر نامههاى آموزش خانو اده بايد مورد توجه قرار گيرد. تشـكر و قدردانى: اين بثزوهش بر گرفته از بايان نامه كارشـناسى ارشد خانم

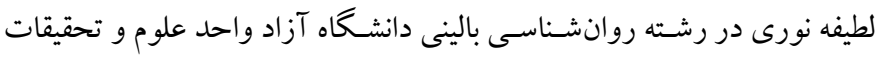

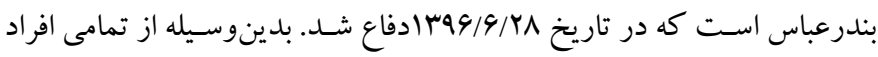
نمونه كه در اجراى اين يزوهش مشار كت داشتند و مهد كود ككهاى شهر ستان

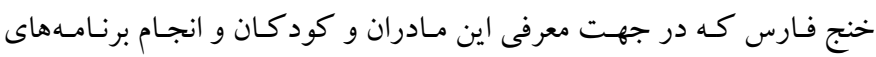

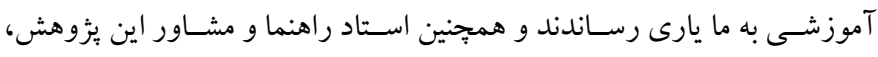
تشكر و قدردانى مى شود.

تضــاد منافع: اين يُوهش براى نويســد كان هيج گَونه تضــاد منافع به دنبال

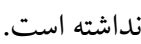

را درباره نقش والدگرى بالا خو اهد برد و همجِنين به آنها كمك مى كند تا رفتارهاى نامناسب فرزند خود را مهار كرده و كاهش دهند و در تربيت آنها احســاس موفقيت بيشـترى داشـته باشـــد (N). همجنين مزيت اين روى آورد برخلـاف سـاير شــيوههـا كـه فقط تأكيد بر حذف رفتارهاى

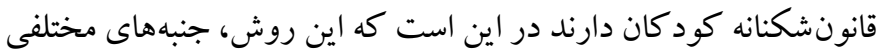
از عملكرد والدينى و ساختار كل خانو اده را مورد توجه قرار مى دهد، به

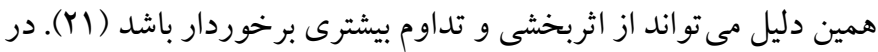

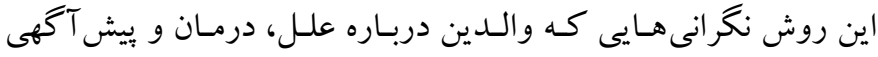
اختلال فرزندشان دارند، در جلسات آموزشى، اصلاح شده و حمايت للازم براى والدين فراهم مىشـود (YY). از سـويى ديخر اثربخشسى بايدار اين روى آورد از اين جهـت اسـت كـه كـار كرد خـانو اده را از طريق ايجاد تغييرات شـناختى - رفتارى والدين، اصلاح محيط تعاملى كود كى، اصلاح سبك هاى ناكام كننده والدينى، ارتقا مىبخشد (YF). نتايج يزٔوهش حاضـر، نشــان دهنده نخاه بومى به روش هاى متداول

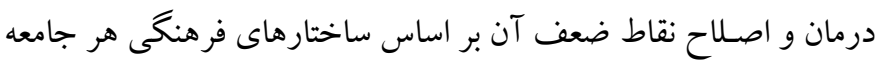

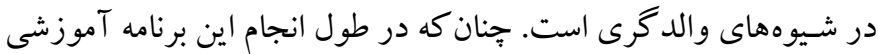
مشـصص شد، مادران بر اين باورند كه آنان سهم بيشترى نسبت به يدران در شكل گيرى و تداوم اين اختلال دارند؛ به همين خاطر در طول جلسات تلاش شـد كه اين نخرش حذف و با اصـلاح احسـاس گناه مادران و نغاه بدبينانه يدران به فرزندشـان، سـهم برابرى در مديريت رفتار والدين در برخورد با اين كود كان ايجاد شود.

دشــوارى در غربال كرى اختلالات همبود، عدم همســانســازى اين كودكـان از لحساظ ظرفيـتهــاى شــــاختى و يـاد كيرى، عـدم كنترل اختلال هاى همر اه با خانو ادهها و ناهمسويى آنان از لحاظ سطح اجتماعى، اقتصادى و آموزشى، كنترل بايين تأثير همزمان ساير برنامههاى آموزشى بـى بـ 


\section{References}

1. Al-Jawadi AA, Abdul-Rhman S. Prevalence of childhood and early adolescence mental disorders among children attending primary health care centers in Mosul, Iraq: a cross-sectional study. BMC Public Health. 2007; 7(1): 274. [Link]

2. Karimi M, Keikhavani S, Mohammadi MB. Efficacy of social skills training on behavioral disorders among elementary school children. Scientific Journal of Ilam University of Medical Sciences. 2010; 18(3): 6-68. [Persian]. [Link]

3. Fanti KA, Henrich CC. Trajectories of pure and cooccurring internalizing and externalizing problems from age 2 to age 12: Findings from the NICHD study of early child care. Dev Psychol. 2010; 46(5): 11591175. [Link]

4. Heward WL. Exceptional children: An introduction to special education. 10th Edition. Boston: Pearson; 2012; pp: 29-30. [Link]

5. Fortin L, Lessard A, Marcotte D. Comparison by gender of students with behavior problems who dropped out of school. Procedia Soc Behav Sci. 2010; 2(2): 5530-5538. [Link]

6. Ştefan CA, Miclea M. A preliminary efficiency study of a multifocused prevention program for children with deficient emotional and social competencies. Procedia Soc Behav Sci. 2010; 5: 127-139. [Link]

7. Rutter M, Kim-Cohen J, Maughan B. Continuities and discontinuities in psychopathology between childhood and adult life. J Child Psychol Psychiatry. 2006; 47(34): 276-295. [Link]

8. Ghobari-Bonab B, Parand A, Hossein Khanzadeh Firoozjah A, Movallali G, Nemati S. Prevalence of children with behavioral disorders in primary schools in Tehran. Journal of Exceptional Children. 2009; 9(3): 223-238. [Persian]. [Link]

9. Ghasemi O, Mousavi-Ghahfakhri A. personality assessment of childern in elementary school. Behriar Pud, Delijan. 2016; 22-34. [Persian].

10. US Department of Health and Human Services, US Department of Education, US Department of Justice. Report of the surgeon general's conference on children's mental health: a national action Agenda. Washington (DC): US Department of Health and Human Services; 2000. [Link]

11. Hester PP, Baltodano HM, Hendrickson JM, Tomelson SW, Conroy MA, Gable RA. Lessons learned from research on early intervention: What teachers can do to prevent children's behavior problems. Prev Sch Fail. 2004; 49(1): 5-10. [Link]

12. Hacker K, Arsenault L, Franco I, Shaligram D, Sidor M, Olfson M, et al. Referral and follow-up after mental health screening in commercially insured adolescents. J Adolesc Health. 2014; 55(1): 17-23. [Link]

13. Hacker KA, Penfold R, Arsenault L, Zhang F, Murphy M, Wissow L. Screening for behavioral health issues in children enrolled in massachusetts medicaid. Pediatrics. 2014; 133(1): 46-54. [Link]

14. Stifler MC, Dever BV. Mental health screening at school: instrumentation, implementation, and critical issues. 1st ed. Cham: Springer International Publishing; 2015, pp: 21-22. [Link]

15. Walker HM, Severson HH, Todis BJ, Block-Pedego AE, Williams GJ, Haring NG, et al. Systematic screening for behavior disorders (SSBD): further validation, replication, and normative data. Remedial Spec Educ. 1990; 11(2): 32-46. [Link]

16. Lane, K.L., Oakes, W.P., \& Menzies, H.M. (2014). Comprehensive, integrated, three-tiered models of prevention: Why does my school-and district - need an integrated approach to meet students' academic, behavioral, and social needs? Preventing School Failure: Alternative Education for Children and Youth, 58, 121-128. [Link].

17. Kilgus SP, Sims WA, von der Embse NP, RileyTillman TC. Confirmation of models for interpretation and use of the Social and Academic Behavior Risk Screener (SABRS). Sch Psychol Q. 2015; 30(3): 335352. [Link]

18. Goodman R. The strengths and difficulties questionnaire: a research note. J Child Psychol Psychiatry. 1997; 38(5): 581-586. [Link]

19. Goodman R, Ford T, Simmons H, Gatward R, Meltzer $\mathrm{H}$. Using the strengths and difficulties questionnaire (SDQ) to screen for child psychiatric disorders in a community sample. Br J Psychiatry. 2000; 177: 534539. [Link]

20. Lane K, Menzies H, Oakes W, Kalberg J. Systematic screenings of behavior to support instruction: From preschool to high school. 1 edition. New York: Guilford Press; 2012, pp: 10-11. [Link]

21. Sarmad Z, Bazargan A, Hejazi E. Reseach methods in behavoral science. Tehran: Agah; 2015, pp: 77-79. [Persian].

22. Comrey AL, Lee HB. A first course in factor analysis. 2nd Edition. Hillsdale, NJ: Psychology Press; 1992, pp: 205-213. [Link] 
23. Chronbach LJ. Coefficient alpha and the internal structre of tests. Psychometrika. 1951; 16(3): 297-334. [Link]

24. Tabachnick BG, Fidell LS. Using multivariate statistics. 5th Edition. Oston, MA: Allyn \& Bacon/Pearson Education; 2006, pp: 660-670. [Link]

25. Kaiser HF. An index of factorial simplicity. Psychometrika. 1974; 39(1): 31-36. [Link]

26. Bartett MS. Tests of significance in factor analysis. $\mathrm{Br}$ J Math Stat Psychol. 1950; 3(2): 77-85. [Link]

27. Kheiry H, Salehi I, Soltani Shal R. The effectiveness of stress management training on marital satisfaction and parental stress in mothers with children with behavioral problems. Journal of Child Mental Health. 2018; 4(4): 3-13. [Persian]. [Link]
28. Akbari-Zardkhaneh S, Alebuieh M, Zanganeh A, Mansurkiaie N, Jallalat-Danesh M, Mahdavi M. Parent form of psychological pathology for children: preliminary study of development and psychomentric properties. Journal of Child Mental Health. 2018; 4(4): 152-164. [Persian]. [Link]

29. Houman HA. Multivariate analysis in behavioral research. Tehran: Parsa Publication; 2001, pp: 395404. [Persian].

30. Mitchell ML, Jolley JM. Research design explained. 8 edition. Australia, Belmont, CA: Wadsworth Publishing; 2012, pp: 112-113. [Link]

31. Naghavi A, Fatehizadeh MAS, Abedi MR. A study on abused girls and the consequences of abuse on them. Women in Development \& Politics. 2004; 2(3): 125145. [Persian]. [Link] 